UDC $519.8(045)$

DOI: $10.18372 / 1990-5548.56 .12944$

\author{
${ }^{1}$ A. A. Aralova, \\ ${ }^{2}$ N. I. Aralova, \\ ${ }^{3}$ O. M. Klyuchko, \\ ${ }^{4}$ V. I. Mashkin, \\ ${ }^{5}$ I. V. Mashkina
}

\title{
INFORMATION SYSTEM FOR THE EXAMINATION OF ORGANISM ADAPTATION CHARACTERISTICS OF FLIGHT CREWS' PERSONNEL
}

\begin{abstract}
${ }^{1,2,4}$ Institute of Cybernetics of V. M. Glushkov National Academy of Sciences of Ukraine, Kyiv, Ukraine
${ }^{3}$ Educational \& Research Institute of Air Navigation, National Aviation University, Kyiv, Ukraine

${ }^{5}$ Borys Grinchenko Kyiv University, Kyiv, Ukraine

E-mails: 1,2 aralova@ukr.net, ${ }^{3}$ iesy@nau.edu.ua,, ${ }^{4}$ mashkin_v@ukr.net, ${ }^{5}$ mashkina.iv@gmail.com

Abstract - An information system is proposed for the examination of flight crew members' functional states; the system is based on the concept of human's organism's oxygen regimes control. It was implemented on the base of the database managing system and the Lasaru programming system. This electronic information system includes two automated work place; the list of their functions and functions' descriptions are described as well. These automatic work places allow providing of significant practical support in solving of set of tasks that are linked with improvement of organism state, development of the general physical qualities and the special physical training of flight crews' members.
\end{abstract}

Index Terms - Functional state of operator; operator efficiency; integral estimation; regressive model; estimation of the state of flight crews' personnel.

\section{INTRODUCTION}

The human health and adaptation to flight work is a state that characterized by the effective performance by human of it biological, labor and social functions, by the rational mobilization of energy resources of organs, systems and the whole organism, by the adaptation to the influence of flight environment extreme factors. Reliability and health of pilot depend, first of all, on the reserves of his capacity for adaptation [1], [2].

Studying the dynamics of aviators functional state in process of their professional activity with the help of physiological research methods allows with a high degree of reliability to estimate their organisms' potential capabilities and to diagnose changes in the functional state under the influence of various factors and loads, both different according to their complexity and degree of influence. Some authors [3] have found that the regulatory systems of pilots' bodies are under especially hard influence of combined effects of extreme factors.

Flight work is going in special conditions that differ significantly from other types of professional activity. During the flight, the pilot's body is under the influence of complex set of factors of changed environment, acceleration and overload, differences in barometric pressure and temperature, rocking, noise, vibration. Also, considerable inconveniences during the work are the results of pose stiffness, flying suit and special equipment, the need to use oxygen-respiratory equipment. Unlike other professions linked with the management of complex machines and aggregates, the pilot interacts with two dynamic systems simultaneously: he controls the work of engines and aircraft mechanisms and performes the movement of the aircraft in a threedimensional space. Under these conditions he must perform a large number of generalization operations during the short time intervals of information flows from the numerous indicators of airplane and equipment management [4], [5].

\section{PROBLEM STATEMENT}

The pronounced organism reaction on adverse factors of flight work influence is determined by the strength and length of the action. Besides of this, the response-reaction will be determined by the complex influence of the initial organism functional state and its reactivity that depends on many conditions of the internal and external environment, state of organism health, ability to distribute properly their forces for the entire time of work, the ability to apply correctly breathing techniques and techniques of protective muscle tension, as well as the concomitant effects of other extreme environmental factors and flights. Responses-reactions of organism can have both adaptive type, as well as to reflect cumulative damaging effects of extreme loadings [3], [5] and [6]. 
Overloadings on modern aircraft are characterized by the significant numbers (up to 9 units) and, this is the most important, by a high speed of their increase (up to 5-7 units/s), which reduces their portability, and requires the implementation of measures for the special training of pilots [7] - [9] Thereby, the actuality of researches aimed on the studying of tolerance to aerodynamic overloads by pilots who flights on manoeuvrable aircrafts and the development of methods for resistance increasing to these effects, especially after breaks, is currently increasing.

The estimation of functional capabilities and the degree of physical pilot fitness to the influence of aerodynamic overloads is carried out currently when performing a staggerometric test, which is based on the creation of static muscular effort [10].

In works [11], [12], based on the methods of the theory of reliability, a model of reliability of the functional state of operators of the system of continuous interaction, which also includes persons of flight crews (in the form of a chain with a "weak link"), is proposed. There also were grounded that the "weak links" of pilots are the respiratory system and system of psycho-physiological functions. So, it is obvious that when performing the staggerometric test there is a need to inspect the respiratory functional system, which provides the pilots ability to perform the set of training and combat tasks. It is clear that such an examination involves the need to process and accumulate the large volumes of information [13], [14], which needs to be processed, stored, compared and analyzed thus, it is necessary to develop the appropriate mathematical, algorithmic and software means.

The purpose of present work was to create an automated information system for diagnosing a pilots' functional respiratory system.

This system would allow to:

- implement a diagnostic algorithm for the estimation of functional status of flight crew members;

- accelerate repeatedly processing of the data obtained during pilots inspection;

- accumulate in centralized manner the information for its pre-processing, storage and collective use;

- develop an algorithmic device for providing of the opportunity to prove scientific hypotheses, to develop options for optimization of decisions when assessing the professional suitability of flight crew members.

\section{PROBLEM SOLUTION}

\section{A. Organism's oxygen regimens and their regulation}

At present, one of the most effective and relatively simple methods to obtain the information about the respiratory system functional state is the estimation of organism's oxygen regime (OOR) and the phased oxygen delivery to human body. This method is based on the concept proposed in [15] about the regulation of organism's oxygen regimes, according to which there are two linked groups of parameters of oxygen transport speed and its partial pressure and pressure at the main stages of its path in human body (lungs, alveoli, arterial blood, mixed venous blood). Analysis of these two groups of parameters combination allows us to characterize the function of body's system of oxygen supply both quantitatively and qualitatively.

This approach allows us to obtain general characteristics of gas homeostasis with a minimum of indicators, to give it detailed analysis involving the fundamental mechanisms that provide the transport of respiratory gases, to carry out the diagnosis of the main syndromes associated with disruptions of the gas transportation function, to give the oxygen "portrait" of the organism and its dynamics at various functional states, to estimate the organism ability to recover itself from external and internal disturbances. The systematic accumulation of these data, their systematization and subsequent processing and analysis provide the possibility of recognition and objectivity of characteristics of large number of flight crews' personnel, which are examined. All this makes possible to follow the changes in dynamics of key indicators in process of general physical training of pilots, which contributes to the recovery and improvement of organism and the development of general physical qualities and special physical training, which is professionally oriented and directed primarily to increase the body's resistance to overloads that are happening during flights. Special physical training develops and improves physical qualities such as muscular strength and static muscular strength, which are professionally important for pilots of maneuverable aviation [16].

\section{B. Structural scheme of information system}

With the development of the use of mathematical apparatus and capabilities of modern computer technologies to improve the means and methods of operational collection, processing and analysis of the data from a complex study of flight personnel on the basis of database managing system (DBMS) and Lasarus programming system, an information system (IS) was developed and implemented, its block diagram is presented on Fig. 1. Information system allows: to accelerate processing of the data obtained during inspection of pilots; to implement diagnostic algorithm for assessing of the functional state of 
flight crews' members; to centralize the accumulation of information for its pre-processing, storage and collective use; to develop an algorithmic device for providing of the opportunity to prove scientific hypoteses, to develop options for decisions optimizing during estimation of professional suitability of flight crews' members.
In the database (DB), which is a part of IS, the information about each person who has undergone the examination is collected, including questionnaire data, hours of exposure, data on special technical and physical state, and the results of comprehensive survey that is performed for the estimation of respiratory system.

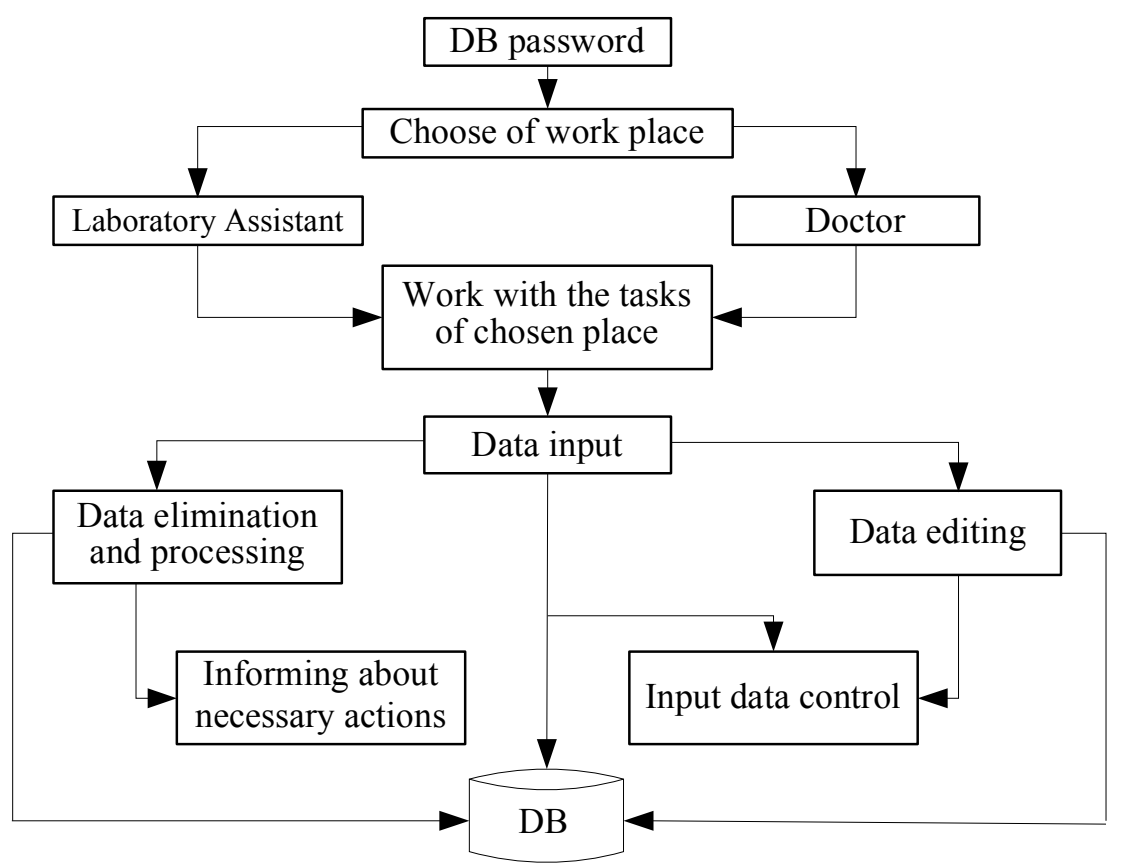

Fig. 1. Block diagram of automated information system (AIS)

Since IS organization suppose the data structure that reflects the various diverse pilots' characteristics, its development has become a prerequisite for the solution of many tasks related to the estimation of flight personnel professional adaptation. Accumulation of structured information in the database provides effective means for:

- collective use of information in a mode with many users (multi-users mode);

- obtaining of enquiry on all information arrays or on individual fragments, including an arbitrary set of conditions that is defined by the user;

- constructing of series of indicators values from DB structure and their transfer for statistical processing of results;

- automation of evaluation process of the results of testing with the subsequent integration of indicators of different aspects of pilots preparedness;

- formation of output documents, tables, graphs, reports, histograms for different categories of users;

- conducting a retrospective analysis of the training of flight crews' members who have achieved significant results in special training for generalizing of psychological, physiological, sociological factors, experience of initial basic training, which provided the background and improvement of flying skills.
During the development of the IS, two automated work places (AWP) were provided - "Doctor" and "Laboratory Assistant". This division was due to the fact that data collection during survey requires a set of specific knowledge and skills, while for the recording of initial information, anthropometric studies, blood sampling for analysis, this knowledge did not needed. Besides of this, the blood tests are carried out in the laboratory but not at the workplace. Indicators that characterized the state of the system of external and alveolar respiration, cardiac activity, and blood circulatory system are recorded directly at the workplace and can be input by the Doctor. The block diagram of IS of the Doctor is presented on Fig. 2. The units of the Doctor's AWR are shown on Fig. 2, they perform following functions (Table I).

\section{The algorithm of system functioning}

The system functioning algorithm is following. After logging in to the "Laboratory Assistant" AWP, user input general data about examined person: last name, age, qualification, hours of flight, preparation, and etc. The system has the ability to form groups by age, qualification, training, and etc. After that, the examination applications for defined group under the specified condition are being prepared. 
TABLE I. DOCTOR'S AWR UNITS’ FUNCTIONS

\begin{tabular}{|l|l|}
\hline DBMS & $\begin{array}{l}\text { Managing mechanisms, editing and the work with the system data at DB } \\
\text { level }\end{array}$ \\
\hline Tables, stored procedures, triggers & $\begin{array}{l}\text { Instruments for DBMS management that were provided by developers for } \\
\text { the optimization of access to the data, in dependence on the tasks that are } \\
\text { solved (non-accessible for user) }\end{array}$ \\
\hline The work with DB unit & $\begin{array}{l}\text { Provides interaction between DBMS and users via above described in- } \\
\text { struments }\end{array}$ \\
\hline Control unit (program) & $\begin{array}{l}\text { Provides the calculations, connection with DBMS, fulfillment of users' } \\
\text { tasks }\end{array}$ \\
\hline $\begin{array}{l}\text { Units of work with reports, work on } \\
\text { experiments, work with applications, } \\
\text { work on analyzes and results, work } \\
\text { with contracts, work with clients }\end{array}$ & $\begin{array}{l}\text { Sub-tasks of the AWP, that are fulfilled through interaction with the user } \\
\text { via dialog interfaces }\end{array}$ \\
\hline
\end{tabular}

On the basis of examination applications, the collection of general data from external environment is carried out (barometric pressure, partial pressure of water vapor, altitude, temperature at environment, and etc.). A blood samples for analysis are also carried out. Further, the "Doctor" examines respiratory system, geodynamics, cardiac activity in a state of the rest and during the loading (veloergometric load possible, step-test, statoergometric test), depending on the purpose of survey. When all necessary data for the calculation are input, the program calculates the organism's oxygen regimes and distributes them in groups according to different parts of respiratory system. Also, the indicators that characterize velocity, intensity of the phased oxygen delivery as well as indicators characterizing the efficiency of respiratory system and blood flows, parameters that characterize the hypoxic state of the organism are determined. Transactions within the framework of one application can be performed multiple times.

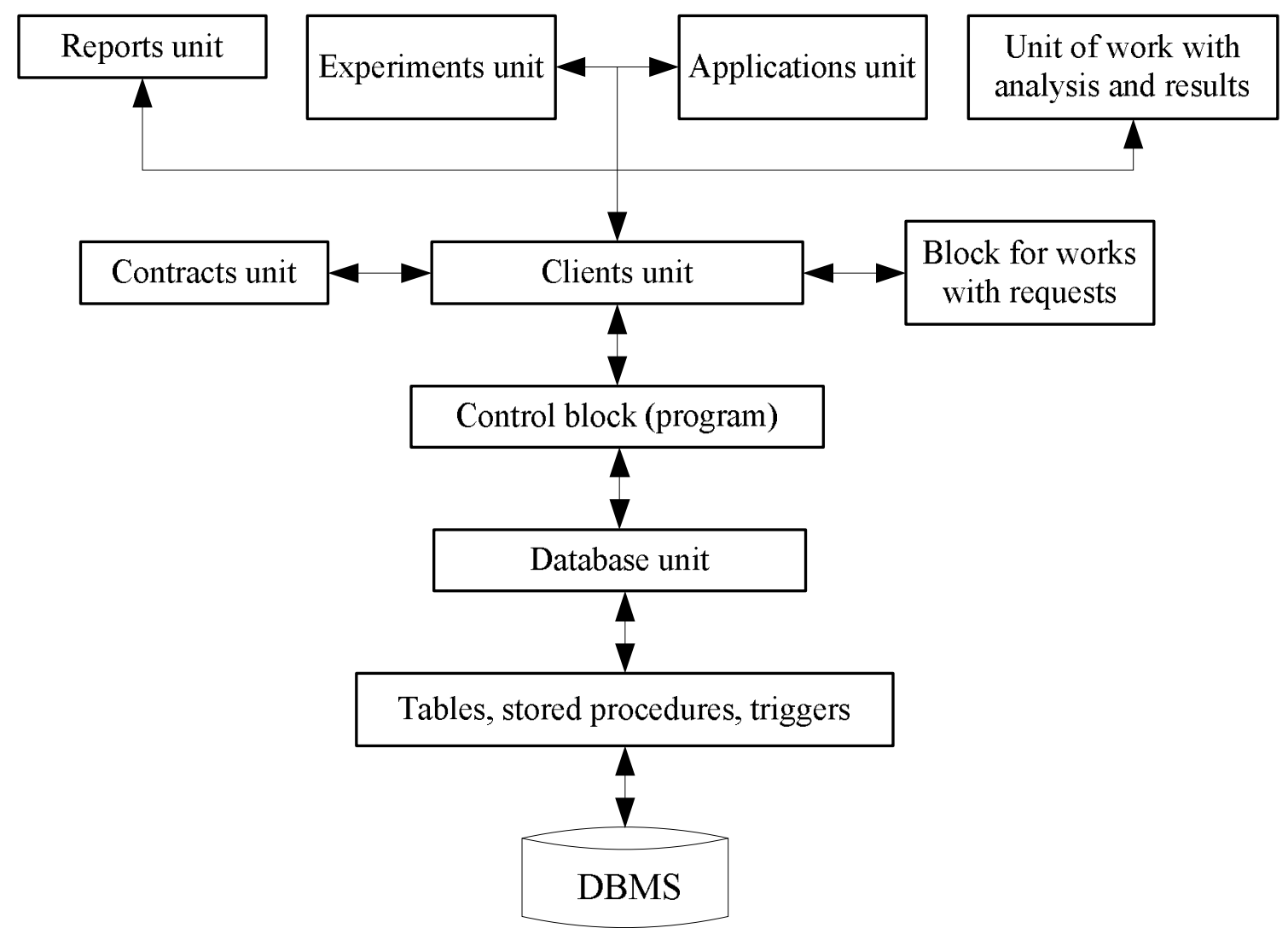

Fig. 2. Block diagram of automated work place (AWP) "Doctor" 


\section{Information system software}

Block diagram of IS software is presented on Fig. 3. Such software distribution allows performing the functions assigned to it optimally. Let's describe the functions, internal and external data of individual units in details.

Initial data input unit. Provides the correct input of the data about the examined personnel group, the state of groups' organisms at different moments of examination, it includes also verification of the data compatibility.

Regular Data Input Unit. Provides correct input of general human data-characteristics: name, last name, age, qualification, flying hours, and etc. The results are recorded in the database.

Personal data input unit. Provides correct view of anthropometric data, data of laboratory research. The results are recorded in the database and used in current calculations.
Examination data input unit. Ensures the correct input of examination data. The results are recorded in the database.

Incoming data maintenance unit. Provides the data storage in the database. Recording takes place either automatically or according to user directives.

Mathematical solver unit. Constructs and performs calculations.

Result submission unit. Performs graphical and table representation of the results of the work.

Reports maintenance unit. At the request from the user, forms the report about the work done.

Developer info[rmation] unit. Provides an information about developers with the contact data.

HELP unit. Provides contextual help, instructions and advices for user from any task.

Exit from the system unit. Provides correct output, saving of parameters and current data through user dialogue.

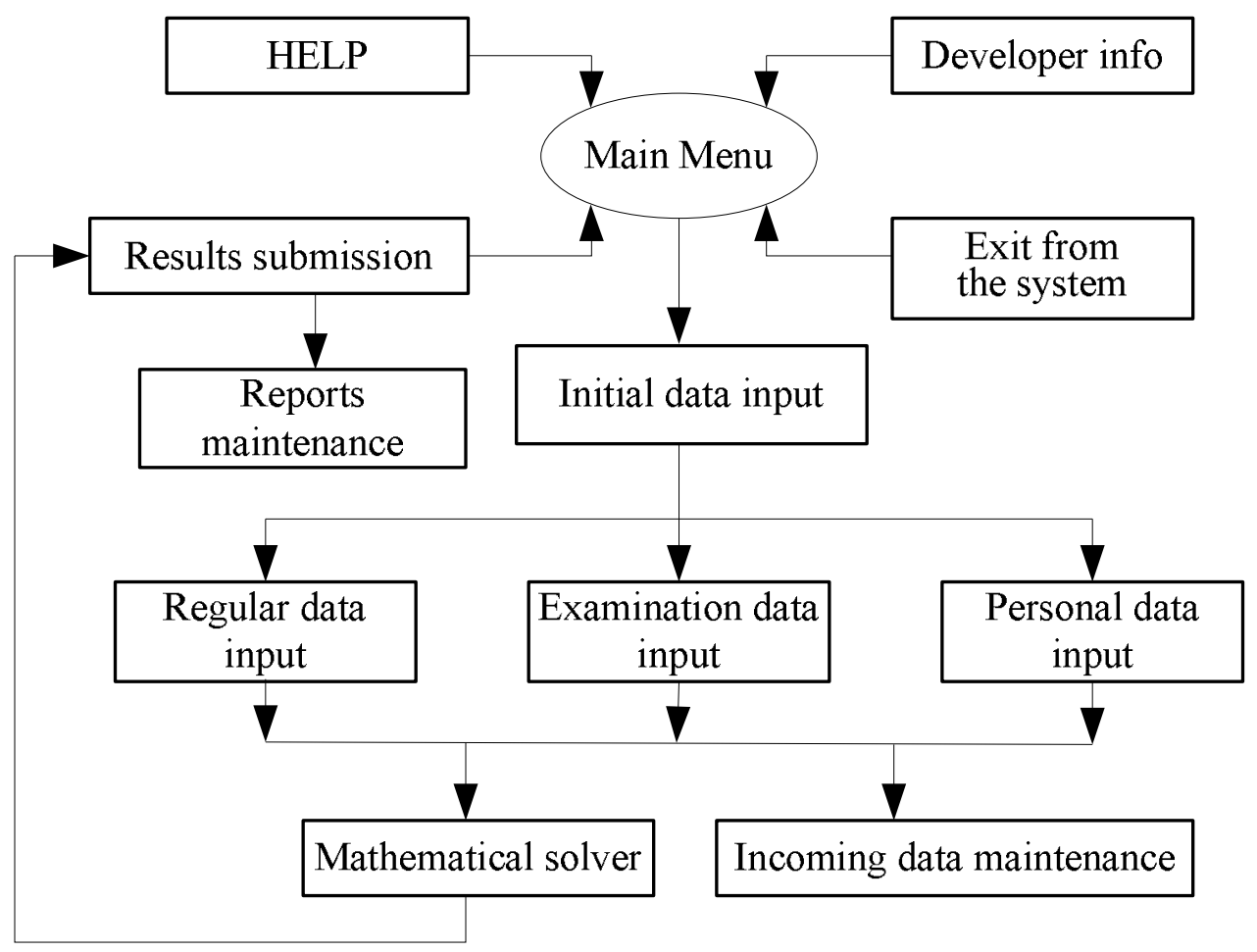

Fig. 3. Automated information system (AIS) software scheme

The crucial unit is the Main Menu, which is defined by the tasks of the user's AWP. General units for both AWRs are "Help", "Developer info", "Exit" units. In other units there are functional divisions depending on the tasks solved by these AWRs. In particular, the "Mathematical solver" unit does not participate in the work of AWR "Laboratory Assistant" and is an exclusive part of AWR "Doctor". "Regular data input" and "Personal data input" are exclusive only for AWP "Laboratory Assistant".

On the other hand, units "Reports maintenance",
"Submission of results" and "Initial data input" works in each AWR according to the same principles, but with different data.

Since the AWP are implemented on the basis of the DBMS, this enabled to use such powerful tool as report editor. Thus, based on the data ordered in the database, we can perform a statistical survey and data processing according to different criteria and present the results in documented and normative terms that are available for further processing by standard text editors. 


\section{CONCLUSION}

This information system has proven itself well in practice of examining of athletes who specialize in cycling sports (highway cycling, speed skating, rowing), martial arts (freestyle wrestling), and alpinists of high-level qualification. This system also can provide significant support for the solution of complex of tasks connected with the organism improvement and with the development of general physical characteristics and special physical training of flight crews' members; training that is professionally oriented and aimed on the increasing of resistance to the influences of piloting overloads. This automated information system permitted the implementing of diagnostic algorithm for the estimation of functional state of flying crews' members.

\section{REFERENCES}

[1] E. V. Malysheva, A. V. Gulin, and K. I. Zasyadko, "Estimation of the state of pilot tension and adaptation to negative factors of flight activity," Bulletin of Tambov University. Series of Natural and Technical Sciences. Tambov, 2011, vol. 16, Issue. 1, pp. 316-318 (in Russian).

[2] B. A. Adamovich, R. M. Baevsky, A. P. Berseneva, and I. I. Funtova, "Problem of the automated estimation of astronautics organism functional state and preventive medicine at the present stage," Kosm. biol. and aerospace medicine. vol. 24, no. 4, pp. 1-18, 1990, (in Russian).

[3] E. V. Malysheva, A. V. Gulin, and K. I. Zasyadko, "Cumulative damaged effects of extreme loading at operators of flight speciaities," Bulletin of Tambov University. Series of Natural and Technical Sciences. Tambov, 2011, vol. 16, Issue. 1, pp. 319-321, (in Russian).

[4] N. N. Artamonov, "Features of the course, diagnosis and prophylaxis of diseases in flight crews," Aviation medicine: guidance. Moscow, 1986, pp. 451-462, (in Russian).

[5] R. M. Bayevsky, "Estimation and classification of health levels from the point of view of adaptation," Bulletin AMN. 1989, no. 8, pp. 73-78, (in Russian).

[6] A. A. Aydaraliev and A. L. Maksimov, "Human adaptation to extreme conditions," Experience of forecasting. Leningrad, Science, 1988, 26 p. (in Russian).
[7] L. S. Malashchuk, Yu. E. Maryashin, and V. N. Filatov, "To the question of human functional reliability in extreme types of activity," Problems of flight safety, no. 5, pp. 21-27, 2012, (in Russian).

[8] D. A. Nikiforov, A. A. Vorona, A. V. Bogomolov, and Yu. A. Kukushkin, "Methodology for assessing of potential unreliability of pilot's actions," Safety of life, no. 7(175), pp. 7-16, 2015, (in Russian).

[9] L. S. Malashchuk, and V. N. Filatov, "Problematic issues of studying of radial accelerations tolerance to the flight composition," Problems of flight safety, no. 9, pp. 6-11, 2013, (in Russian).

[10] G. Yu. Klishin and V. N. Filatov, "Informationmeasuring system of statoergometric testing of flying crews' personnel," Program Systems and Computational Methods, no. 2, pp. 136-149, 2016, (in Russian).

[11]N. I. Aralova, "The complex of informational support for operator of the systems of non-interrupted interaction in conditions of the higher situational tension," Science and innovation, vol. 12 (2), pp. 15-25, 2016, (in Russian).

[12] N. I. Aralova, O. M. Klyuchko, V. I. Mashkin, and I. V. Mashkina, "Software for the reliability investigation of operator professional activity for "human-machine" systems," Electronics and control systems, no. 1(51), pp. 107-115, 2017.

[13]N. I. Aralova, "Evaluation of respiratory functional system, oxygen regimes of human organisms and the degree of hypoxia (a set of programs for PC)," Physiol. Journal, 42. 3-4, 96 p., 1996, (in Russian).

[14]A. A. Aralova, N. I. Aralova, L. A. KovalchukKhimyuk, and Yu. N. Onopchuk, "Automated information system for athletes functional diagnostics," Control systems and machines, no. 3, pp.73-78, 2008, (in Russian).

[15]A. Z. Kolchinskaya, N. V. Lauer, and E. A. Shkabara, "On the regulation of organism oxygen regimes," in book "Organism oxygen regime and its regulation," Kiev: Naukova Dumka, 1966, pp. 349-556.

[16]K. I. Zasyadko, E. A. Flenov, A. P. Vonarshenko, and M. N. Yazlyuk, "The method of physical training of the flight crews for the formation of psychophysiological resistance to maneuvering overloads influence," Health issues, no. 2, pp. 52-62, 2016. DOI:10.7256/2453-8914.2016.2.19800 URL: http://e-notabene.ru/zdravo/article_19800.html

Received February 21, 2018.

Aralova Albina. Candidate of Science (Physics and Mathematics). Scientific researcher.

Institute of Cybernetics of V. M. Glushkov National Academy of Sciences of Ukraine, Kyiv, Ukraine.

Education: National Technical University of Ukraine "Kyiv Politechnical Institute", (2009).

Research area: mathematical modeling, numerical methods, problems of mathematical physics.

Publications: 26.

E-mail: aralova@ukr.net

Aralova Nataliya. Candidate of Science (Engineering). Senior researcher.

Institute of Cybernetics of V. M. Glushkov National Academy of Sciences of Ukraine, Kyiv, Ukraine.

Education: National University named after Taras Shevchenko, Kyiv, Ukraine, (1978).

Research area: control in biological and medical systems. 
Publications: 103.

E-mail: aralova@ukr.net

Klyuchko Olena. Candidate of Science (Biophysics). Associate Professor. Senior researcher.

Educational \& Research Institute of Air Navigation, National Aviation University, Kyiv, Ukraine.

Education: National University named after Taras Shevchenko, Kyiv (1981), National Aviation University, Kyiv, Ukraine, (2003).

Research area: biophysics, ecology, bioinformatics, brain sciences.

Publications: 180.

E-mail: iesy@nau.edu.ua

Mashkin Valery. Candidate of Science (Engineering). Senior researcher.

Institute of Cybernetics of V. M. Glushkov National Academy of Sciences of Ukraine, Kyiv, Ukraine.

Education: Kyiv Polytechnic Institute, Kyiv, Ukraine, (1967).

Direction of scientific activity: management of complex technical systems.

Publications: 72.

E-mail: mashkin_v@ukr.net

Mashkina Irina. Candidate of Science (Engineering). Associate Professor.

Borys Grinchenko Kyiv University, Kyiv, Ukraine

Education: Maxim Gorky Kyiv Pedagogical Institute, Kyiv, Ukraine, (1984).

Direction of scientific activity: modeling of processes and systems.

Publications: 69.

E-mail: mashkina.iv@gmail.com

А. А. Аралова, Н. І. Аралова, О. М. Ключко, В. Й. Машкін, І. В. Машкіна. Інформаційна система для вивчення адаптаційних характеристик організму осіб льотного складу

Запропоновано автоматизовану інформаційну систему для дослідження функціонального стану осіб льотного складу, яка базується на концепції регулювання кисневих режимів організма людини. Розробку реалізовано на базі системи керування базами даних та системи програмування Lasarus. Ця електронна інформаційна система включає в себе два автоматизованих робочих місця; наведено список їх функцій, а також опис. Ці автоматизовані робочі місця дозволяють надати суттєву практичну підтримку при розв'язанні комплексу задач, пов'язаних iз покращенням стану організму, розвитком загальних фізичних якостей та спеціальною фізичною підготовкою членів льотних екіпажів.

Ключові слова: функціональний стан організму льотчика; адаптаційні можливості організму; несприятливі фактори льотної роботи.

Аралова Альбіна Андріївна. Кандидат фіз.-мат. наук. Науковий співробітник.

Інститут кібернетики ім. В. М. Глушкова НАН України, Київ, Україна.

Освіта: Національний технічний університет України «Київский політехнічний інститут», (2009).

Напрям наукової діяльності: математичне моделювання, чисельні методи, задачі математичної фізики.

Публікації: 26.

E-mail: aralova@ukr.net

Аралова Наталія Ігоревна. Кандидат технічних наук. Старший науковий співробітник.

Інститут кібернетики ім. В. М. Глушкова НАН України, Київ, Україна.

Освіта: Національний університет ім. Тараса Шевченка, Київ, Україна, (1978).

Напрям наукової діяльності: керування в біологічних і медичних системах.

Публікації: 103.

E-mail: aralova@ukr.net

Ключко Олена Михайлівна. Кандидат біологічних наук (біофізика). Доцент. Старший науковий співробітник. Навчально-науковий інститут аеронавігації, Національний авіаційний університет, Київ, Україна.

Освіта: Національний університет ім. Тараса Шевченка, Київ, Україна, (1981); Національний Авіаційний університет, Київ, Україна, (2003).

Напрям наукової діяльності: біофізика, екологія, біоінформатика, науки про мозок.

Публікації: 180.

E-mail: iesy@nau.edu.ua

Машкін Валерій Йосипович. Кандидат технічних наук. Старший науковий співробітник.

Інститут кібернетики ім. В. М. Глушкова НАН України, Київ, Україна.

Освіта: Київський політехнічний інститут, Київ, Україна, (1967). 
Напрямок наукової діяльності: управління в складних технічних системах.

Публікації: 72.

E-mail: mashkin_v@ukr.net

Машкіна Ірина Вікторівна. Кандидат технічних наук. Доцент.

Київський університет ім. Бориса Грінченка, Київ, Україна.

Освіта: Київський національний педагогічний інститут ім. М. Горького, Київ, Україна, (1984).

Напрямок наукової діяльності: моделювання процесів та систем.

Публикації: 69.

E-mail: mashkina.iv@gmail.com

А. А. Аралова Н. И. Аралова, Е. М. Ключко, В. И. Машкин, И. В. Машкина. Информационная система для изучения адаптационных характеристик организма лиц летного состава

Предложена автоматизированная информационная система для исследования функционального состояния лиц летного состава, которая базируется на концепции регулирования кислородных режимов организма человека. Разработка реализована на базе системы управления базами данных и системы программирования Lasarus. Эта электронная информационная система включает в себя два автоматизированных рабочих места; приведен список их функций, а также описание. Эти автоматизированные рабочие места позволяют обеспечить существенную практическую поддержку при решении комплекса задач, связанных с улучшением состояния организма, развитием общих физических качеств и специальной физической подготовки членов летных экипажей.

Ключевые слова: функциональное состояние организма летчика; адаптационные возможности организма; неблагоприятные факторы летной работы.

Аралова Альбина Андреевна. Канд. физ.-мат. наук. Научный сотрудник.

Институт кибернетики им. В. М. Глушкова НАН Украины, Киев, Украина.

Образование: Национальный технический университет Украины «Киевский политехнический институт», (2009).

Направление научной деятельности: математическое моделирование, численные методы, задачи математической физики.

Публикации: 26.

E-mail: aralova@ukr.net

Аралова Наталья Игоревна. Кандидат технических наук. Старший научный сотрудник. Институт кибернетики им. В. М. Глушкова НАН Украины, Киев, Украина.

Образование: Национальный университет им. Тараса Шевченко, Киев, Украина, (1978).

Направление научной деятельности: управление в биологических и медицинских системах.

Публикации: 102.

E-mail: aralova@ukr.net

Ключко Елена Михайловна. Кандидат биологических наук (биофизика). Доцент. Старший научный сотрудник. Учебно-научный институт аэронавигации, Национальный авиационный университет, Киев, Украина.

Образование: Национальный университет им. Тараса Шевченко, Киев, Украина, (1981); Национальный авиационный университет, Киев, Украина, (2003).

Направление научной деятельности: биофизика, экология, биоинформатика, науки о мозге.

Публикации: 179.

E-mail: iesy@nau.edu.ua

Машкин Валерий Иосифович. Кандидат технических наук. Старший научный сотрудник

Институт кибернетики им. В. М. Глушкова НАН Украины, Киев, Украина.

Образование: Киевский политехнический институт, Киев, Украина, (1967).

Направление научной деятельности: управление в сложных технических системах.

Публикации: 71.

E-mail: mashkin_v@ukr.net

Машкина Ирина Викторовна. Кандидат технических наук. Доцент.

Киевский университет им. Бориса Гринченко, Киев, Украина.

Образование: Киевский национальный педагогический институт им. М. Горького, Киев, Украина, (1984).

Направление научной деятельности: моделирование процессов и систем.

Публикации: 68.

E-mail: mashkina.iv@gmail.com 